\title{
Characterisation and Reverse Engineering of Eco-Friendly Historical Mortar: Qasr Tuba, Desert Castles in Jordan
}

\author{
Ayoup M. Ghrair ${ }^{1,2 *}$, Adi J. Said ${ }^{2}$, Naela Aldaoud ${ }^{2}$, \\ Riham Miqdadi ${ }^{3}$, Ahmad A.L. Ahmad ${ }^{4}$ \\ 1 Water Resources and Environmental Management, Al-Balqa Applied University, Salt 19385, Jordan \\ 2 Nanomaterials for Environmental Applications Research Unit, Foundational Science Research Division, \\ Research for Development Pillar, Royal Scientific Society, Amman, Jordan \\ 3 Department of Tourism and Heritage, United Arab Emirates University, Al Ain, United Arab Emirates \\ 4 Department of Chemistry, University of Maine, Orono, Maine 04469, USA \\ * Corresponding author's email: ayoup.ghrair@bau.edu.jo
}

\begin{abstract}
The purpose of this study was to investigate the mineral composition of the historical mortars of Qasr Tuba and to re-produce them for the restoration process. The mortar samples were collected from the foundation and walls of Qasr Tuba. The chemical and mineral composition of the mortar was determined using several techniques. In addition, the quantitative minerals content was recalculated for the mortar samples utilizing the material balances equation. Moreover, 12 mixtures of mortar were prepared and tested for fresh and hardened properties, according to their respective national and international standards. The results revealed that two types of mortar were used: (i) the lime-based mortar was used for the foundation and joint mortars in the lower parts of the building walls with a gypsum-hydrated lime ratio of 1:3; and (ii) the gypsum-based mortar was used as joint mortar in the upper parts of the building walls for baked bricks at a gypsum-hydrated lime ratio of 4:1. A pozzolanic reaction in the Qasr Tuba mortar produced a new formation of Xonotlite, Stratlingite, and calcium aluminium hydrate as a secondary cementing mineral. In conclusion, the use of hydraulic lime mortar was considered for building an environment for capturing the $\mathrm{CO}_{2}$ gas.
\end{abstract}

Keywords: mortar, grog, lime, gypsum, Qasr Tuba, compressive strength, flexural strength, eco-friendly, historical restoration

\section{INTRODUCTION}

Mortar is among the various construction materials, which refers to the material resulting from the mixture of sand grains, a binder (lime, gypsum, clay minerals, etc.) and water. Properties and characteristics of mortars are classified according to the type of binder used. For some time, mortars had a double objective: to create the link between the parent material (rocks or bricks) as well as to cover and protect the surfaces of columns, walls, and facades (Palomo et al., 2002). Mortars are also of special interest in conservation, because they represent the weakest part of the structure and are much more sensitive to the weathering effects than other components of the building. Therefore, restoration of the mortar is often crucial for the preservation of the whole structure (Omari, 2009).

Mortars have been in use for thousands of years and are integral to most masonry constructions. They are part of most global historical buildings. Therefore, they are a major consideration in building conservation (Hughes et al. 2012). The concern for the study of ancient mortars is relatively new. Engineers and scientists consider historical buildings and investigate the solutions for building performance. Consistently, the outcome were highly efficient buildings, more durable and ecofriendly materials as well 
as lesser energy consumption (Elmeligy, 2016). Válek et al. (2019) reported that mortars are used for the repair of lost portions of surface materials in historical buildings. They recommended that the mortar design and application should be performed in a wider framework of conservation values which included conservation of the original material, the accuracy of approach while conserving integrity, and not only technical principles. In addition, the chemical and physical properties of a repair mortar should be compatible with the substrate and the material being replaced. Groot and Gunneweg (2019) carried out a study on choosing a compatible mortar composition for fill in or repair joints (repointing) of historic masonry under adverse environmental conditions. They found that the quality and durability of repairing work in historic masonry depends on the composition of the repair mortar and good workmanship is a basic requirement for repointing.

In 1981, the International Center for the Study of the Preservation and Restoration of Cultural Property (ICCROM) was founded in order to establish an investigation strategy of ancient and repair mortars. In Spain, such interest has also been declared for more than one decade (Palomo et al., 2002; Luxan et al., 1995). Rossi-Doria (1990) reported that the International Union of Laboratories and Experts in Construction Materials, Systems and Structures (RILEM) established the first classification of mortars as a function of its technical application: (i) mortars for plasters; (ii) mortars for the application of facings; (iii) mortars for decoration; and (iv) masonry mortars. A second classification as a function of the nature of the binder was also created, as follows: (i) mortars based on lime; (ii) mortars based on lime and pozzolanic materials; (iii) mortars based on hydraulic binders; (iv) mortars based on gypsum; (v) mortars based on clay binders; (vi) mortars based on organic binders; and (vii) mortars based on more than one binder.

The first mortars were made of mud and clay. As result of a lack of stone and an abundance of clay, Babylonian structures were constructed from baked brick by employing lime for mortar. According to Ghirshman (1954), the first evidence of humans using mortar was found at the ziggurat of Sialk in Iran in 2900 BC. This structure was built from sun-dried bricks. Similarly, the Chogha Zanbil temple in Iran was constructed around $1250 \mathrm{BC}$ using kiln-fired bricks and a robust mortar comprised of bitumen. In early
Egyptian pyramids built during the years of 2600$2500 \mathrm{BC}$, limestone blocks were held together by mortar comprised of both mud and clay or of both clay and sand (Shaw, 2000). In Egyptian pyramids that were constructed in later times, the mortar was comprised of either gypsum or lime. The gypsum mortar was essentially a mixture of plaster and sand and was determined to be quite soft (HCIA, 2002).

Historically, buildings with a pozzolanic mortar appeared next in Greece. This was found particularly in the underground aqueduct (ca. $500 \mathrm{BC}$ ). The pozzolanic mortar is a limebased mortar with an additive of volcanic ash that allows it to be hardened underwater, thus, it is known as hydraulic cement. Even later, the Romans used a mortar without pozzolana using terra-cotta "crushed baked clay" that introduced aluminum oxide and silicon dioxide into the mix. This mortar was not as strong as the pozzolanic mortar, but it had a better water penetration resistance due to its increased density. (HCIA, 2002; Thomasen and Searls, 1988). Moreover, Herring (2002) reported in his book, The Secrets of Roman Concrete, that the Romans had two different types of mortar. The first one was made with lime and river sand mixed at a ratio of 3:1 sand to lime. The second type used pozzolan and lime mixed at a ratio of $2: 1$ pozzolan to lime. The historical mortar has many advantages. Harrison (2005) reported that the carbonating mortar tends to selfheal the cracks that formed after any movement by crystalline bridging. Moreover, Harrison recommended that in order to achieve good results to reduce global warming, further research needs to be conducted on the carbonating mortars and walls that breathe.

Jordan's architectural heritage is very rich, diversified, and extends over a long-time span. The degradation in this heritage is also rapid and radical as a result of different natural and human causes, including, but not limited to, weathering effects, natural erosion, earthquakes, and the impact of the modern economy and its technology. Therefore, the levels of intervention for conservation and restoration are more urgent than at any time before. Qasr Tuba is an Umayyad desert castle in Jordan that was originally regarded as a desert retreat (Badiyas) for the Umayyad royal family who, being from the desert, grew tired of city life with all of its harshness and crowded environments. Castles, such as Qasr Tuba, allowed the royal family to return to the desert where their 
nomadic livelihood could best be expressed. Qasr Tuba was first recorded by Musil in 1898 (Musil, 1907; Creswell, 1989). It was constructed on a low-lying hill along a trade road using a combination of limestone blocks and baked bricks. The architectural plan consists of a rectangle (140 $\mathrm{m}$ by $85 \mathrm{~m}$ ) and two symmetrical buildings that are connected via a long central corridor (Fig. 1). The building walls are supported by semi-round towers. On the northern side of the castle, two gates are surrounded by two square rooms. The northwestern quadrant remains nearly intact and several lengths of curtain-wall exist on the western side. The rest of the desert castle was never completed and, therefore, is unpreserved. Qasr Tuba has the same characteristics of Qasr alMshatta: (i) the way of building the walls by constructing the lower part by well-dressed stones, above which they are of brick; (ii) the same brick making techniques; (iii) fingers print on plaster; (iv) the effect of the Mesopotamian architecture; (v) tunnel vault, pointed arches, and vaults; (vi) path rooms in the stairs; and (vii) decorations (Creswell,1989).

In order to establish an applicable procedure for the restoration process at Qasr Tuba, the physical, chemical, and mineral content with different concentration of each mineral in the mixture of the construction mortar at the site were investigated. Therefore, the focal point of this study was to create a duplicate mortar from the ancient mortar used in Qasr Tuba and other Jordanian desert castles. This duplicate is an ideal repairing mortar that can restore the same mechanical and chemical composition of the ancient one. This allows the duplicate to be the best alternative for the repairing mortar for its compatibility and durability at the architectural heritage. Moreover, the intention is for it to be used as an eco-friendly construction material in green buildings. The authors believe that this study makes an important contribution towards the ancient Middle East mortars and develops appropriate preservation practices.

\section{MATERIALS AND METHODS}

\section{Study area}

Qasr Tuba is one of the large Islamic desert castles located about $95 \mathrm{~km}$ southeast of Amman in the central Jordanian desert ( $31^{\circ} 19^{\prime} 34.5$; E $36^{\circ} 34^{\prime} 15.8$ ). The castle is situated between wadi Al-Ghadaf in the east and wadi Utarat Al-Ghabasha in the west. It was built by Caliph Walid II (743-744 CE). Due to his death in $744 \mathrm{CE}$ and the collapse of the Umayyad dynasty five years later, the palace was not completed (Lash, 2012). The upper part of walls was built of baked clay bricks of Muwaqqar chalk marl formation, whereas the lower part was built of limestone from the Umm Rijam formation on the eastern margins of the Jordanian desert (Al-Hiyari and Halasa, 2009) (Fig. 2). Pleistocene sediments cover the area around Qasr Tuba. It can be classified into pleistocene gravels, alluvial sediments and mudflats. Pleistocene gravels and alluvial sediments mainly consist of subangular to subrounded clasts of limestone and chert. Mudflats consist of clay and silt, which represent the most recent sediments in

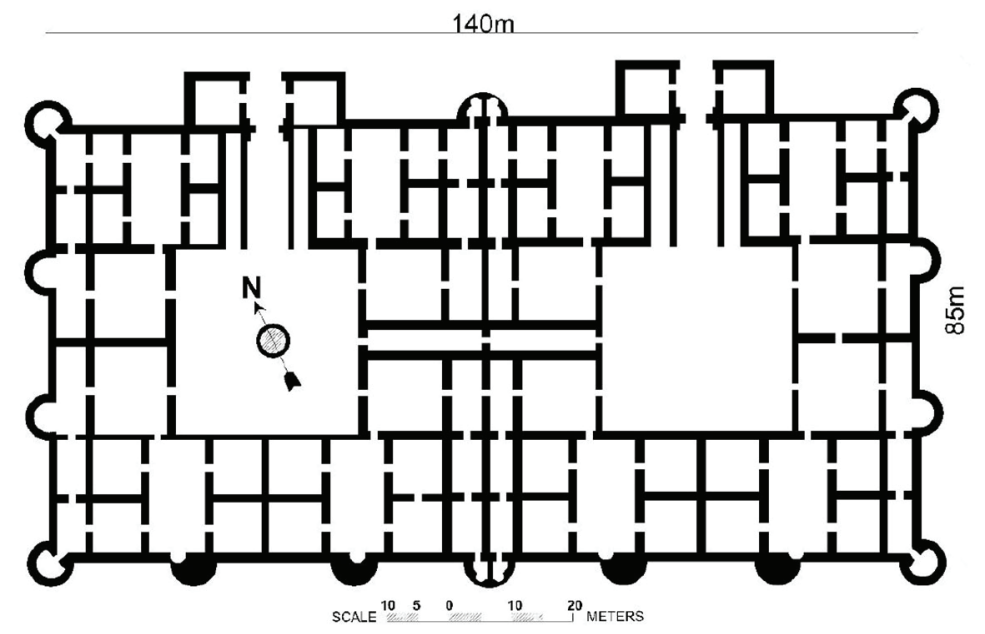

Figure 1. Plan of Qasr Tuba, Jordan Desert Castles. (It was re-drawn by Shahrazad Ghreir, architect engineer at Greater Amman Municipality after Creswell, 1989: 209) 


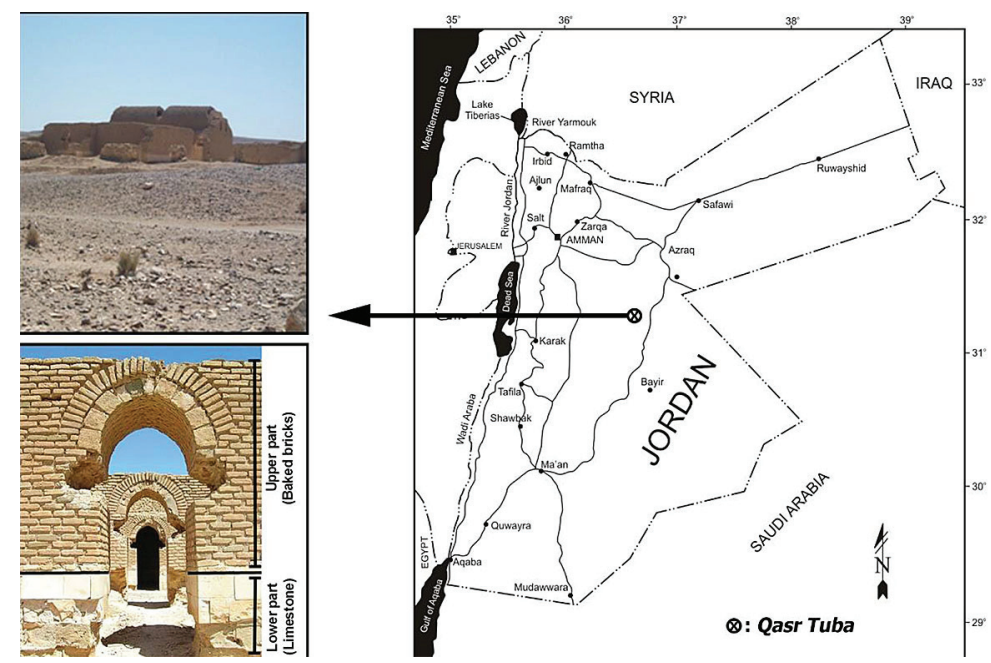

Figure 2. Location map of Qasr Tuba desert castles in the middle Badia.

the study area. The overlaying Muwaqqar chalk marl formation (Maastrichitian) is exposed locally within the east bank of wadi Al-Ghadaf (Al-Hiyari and Halasa, 2009).

The climate of wadi Al-Ghadaf is characterized as a Mediterranean, close to the arid / semiarid climate boundary. The climate is hot in summer and cold in winter. The temperature may reach more than $40^{\circ} \mathrm{C}$ during summer and drop a few degrees below zero in winter. The mean annual rainfall ranges from 50 to $100 \mathrm{~mm}$. Moreover, the humidity is low around $50-60 \%$ during winter and around 15\% in summer (Salameh, 1996).

\section{Methodology}

Two types of mortar samples were collected from the Qasr Tuba-desert castles in the middle Badia. The first one was joint mortar, which was used for building baked bricks at upper parts of the walls (JMUP). The second one was mortar that was used as embedding mortar for foundation or as joint mortar for building limestone at lower parts of the walls (JMLP). Mineral identification of the mortars samples was performed using powder X-ray diffraction ( $\mathrm{Cu} \mathrm{K} \alpha$ radiation) on a Shimadzu X-ray diffractometer (XRD - 6000) at $40 \mathrm{kV}$ and $30 \mathrm{~mA}$. The chemical composition was investigated using X-ray fluorescence spectroscopy (XRF). Homogeneous individual samples of mortar samples from Qasr Tuba were analyzed for the major oxides by XRF (Shimadzu XRF-1800) at $40 \mathrm{kV}$ and $95 \mathrm{~mA}$. The mineral quantity was calculated based on the material balance equation, chemical analyses and mineral quality by the $\mathrm{X}$-ray diffraction patterns. The crystallography and morphology studies were conducted utilizing a stereomicroscope and polarized microscope. The analytical analysis included the compressive strength of mortars, grain size distribution, specific gravity and water absorption, and water content. Mortar cubes and prisms were prepared and cured for the compressive and flexural strength.

Preparatory tests were performed to establish the mortar recipe the mineral content and mixing ratio of which can mimic the original mortar recipe. Material balance equation was used for reverse engineering of the historical mortar. The general equation of material balance for both reacting and non-reacting processes is as follows (Equation 1):

$$
\begin{gathered}
\text { Accumulation within the system }= \\
=\text { (input through system boundaries) }- \\
- \text { (output through system boundaries) }+ \\
+ \text { (generation within the system) }- \\
- \text { (consumption within the system) }
\end{gathered}
$$

Material balance can refer to a balance on a system for the total mass, total moles, mass of a chemical compound, mass of an atomic species, moles of a chemical compound, moles of an atomic species, volume (Chierici, 1994).

\section{Raw Materials}

The following raw materials were purchased and collected from the local market: limestone (calcium carbonate), silica sand (glass sand) also locally known as Swealeh sand, aggregates, kaolin clay, gypsum, plant ash, plant remains (straw) and charcoal. A one-hundred-kilogram sample of ground fine-aggregates $(<5 \mathrm{~mm})$ consisting 
mainly of limestone was purchased from the local construction market and used in mixes without any treatment. The purchased fine aggregate was sieved by sieve no. 100 and the passed powdered material was discarded. Coarse aggregate, locally known as Semsmeyeh, was purchased from the local construction market and then washed with tap water, air dried and stored to be used in mortar and plaster mixes. A one-hundred-kilogram sample of red medium sand stone (Swealeh Sand) with median particle size of $36 \mathrm{~mm}$ was purchased from the local construction market. The biomass of Cypress trees was collected, fired and reduced to ashes at the Royal Scientific Society (RSS) laboratories; then, it was used in mortar and plaster mixes. Natural straw was used in the designed mixes to increase cohesion and prevent crack development when in the hardened state. The used straw was ca. $20 \mathrm{~mm}$ in length. Washed coarse aggregate (Semsmeyeh), fine aggregate (Swealeh sand), and coarse limestone powder (from the type used in plaster's first layer in Jordan) were used in mixes. The physical properties are listed below in Table (1), while the grading is shown in Table (2).

The following natural processed materials were purchased and collected from the local market with construction or industrial grade. A one hundred kilogram sample of hydrated lime $\left(\mathrm{Ca}(\mathrm{OH})_{2}\right)$ samples was purchased from the local market. Portions of this lime powder were soaked in water to produce slaked lime and formulate Lime Putty that can be used as paste in the mixes. Lime putty was prepared by mixing and soaking the hydrated lime in water by $1: 1$ weight ratio for at least two weeks to achieve a good workability. Table (3) shows the chemical composition for the used lime, industrial gypsum powder $\left(\mathrm{CaSO}_{4} \cdot 0.5 \mathrm{H}_{2} \mathrm{O}\right)$, quarts $\left(\mathrm{SiO}_{2}\right)$, meta-kaolin, grog, sodium hydroxide $(\mathrm{NaOH})$, organic maters, ash and carbon.

A one-hundred-kilogram sample of grog samples were purchased from local fired brick factory. The grog samples were prepared by grinding

Table 1. The physical properties of the used aggregate

\begin{tabular}{|l|c|c|c|}
\hline \multicolumn{1}{|c|}{$\begin{array}{c}\text { Aggregate } \\
\text { Type }\end{array}$} & $\begin{array}{c}\text { Bulk Specific } \\
\text { Gravity (SSD) }\end{array}$ & $\begin{array}{c}\text { Absorption } \\
(\%)\end{array}$ & $\begin{array}{c}\text { Fineness } \\
\text { Modulus }\end{array}$ \\
\hline $\begin{array}{l}\text { Coarse } \\
\text { Aggregate } \\
\text { (Semsmeyeh) }\end{array}$ & 2.66 & 1.4 & - \\
\hline $\begin{array}{l}\text { Fine } \\
\text { Aggregate } \\
\text { (Swealeh) }\end{array}$ & 2.6 & 0.3 & 2.5 \\
\hline
\end{tabular}

damaged / failed / cracked / efflorescence fired clay bricks and had been passed through $1.0 \mathrm{~mm}$ sieve. The grog samples were mainly composed of fired kaolin (meta-kaolin) clay material. A bag of $25 \mathrm{~kg}$ industrial grade sodium hydroxide was purchased from the local market. Moreover, a one-hundredkilogram piece of fired clay bricks was also purchased from the local market to be used in testing the physical properties of the formulated mortar and plaster. The brick dimension was $5 \times 7 \times 20 \mathrm{~cm}$. In addition, steel prism $(40 \times 40 \times 160 \mathrm{~mm})$ and cubic $(70 \times 70 \times 70 \mathrm{~mm})$ molds were purchased from the local market for specimens casting.

\section{Mix design}

On the basis of the physical, chemical, characterization and material balance analyses for the collected historical mortar samples, various mixes were prepared and tested at the UKAS accredited construction laboratories at RSS. The fresh and hardened properties of the mixes were evaluated in order to obtain the adequate proportions.

Table 2. The grading of the used aggregate

\begin{tabular}{|c|c|c|c|}
\hline Sieve No. & $\begin{array}{c}\text { Fine } \\
\text { aggregate } \\
\text { Passing } \\
(\%)\end{array}$ & $\begin{array}{c}\text { Coarse } \\
\text { Aggregate } \\
\text { (Semsmeyeh) } \\
\text { Passing (\%) }\end{array}$ & $\begin{array}{c}\text { Limestone } \\
\text { powder } \\
\text { Passing (\%) }\end{array}$ \\
\hline $19 \mathrm{~mm}$ & 100 & 100 & 100 \\
\hline $12.5 \mathrm{~mm}$ & 100 & 100 & 100 \\
\hline $9.5 \mathrm{~mm}$ & 100 & 100 & 100 \\
\hline $4.75 \mathrm{~mm}$ & 98 & 98 & 100 \\
\hline No.4 & 97 & 88 & 100 \\
\hline No.8 & 97 & 7 & 99 \\
\hline No.16 & 96 & 2 & 89 \\
\hline No.30 & 90 & 2 & 69 \\
\hline No.50 & 57 & 2 & 51 \\
\hline No.100 & 9 & 1 & 35 \\
\hline No.200 & 1 & 1 & 24 \\
\hline
\end{tabular}

Table 3. The chemical composition of the used lime

\begin{tabular}{|l|c|}
\hline \multicolumn{1}{|c|}{ Chemical Composition } & $(\%)$ \\
\hline $\mathrm{Ca}(\mathrm{OH})_{2}$ & 99.5 \\
\hline $\mathrm{SiO}_{2}$ & $<0.01$ \\
\hline $\mathrm{MgO}$ & 0.35 \\
\hline $\mathrm{Al}_{2} \mathrm{O}_{3}$ & 0.032 \\
\hline $\mathrm{Fe}_{2} \mathrm{O}_{3}$ & 0.074 \\
\hline $\mathrm{SO}_{3}$ & $<0.01$ \\
\hline Insoluble Matter & $<0.01$ \\
\hline L.O.I. & 24.5 \\
\hline
\end{tabular}


All the designed mixes were studied thoroughly and assigned as No. H1 to H12. The mixes were left for more than 30 days in a steel mold. The mechanical and manual mixing techniques were used and evaluated to find the proper mixing technique. The hardened mortar and plaster were visually inspected and tested for density, water absorption, shrinkage properties, microstructure, thermal gravimetric analysis (TGA) and compressive strength, chemical and physical characteristics. Twelve trial mixtures with different proportions were prepared in order to obtain the best mixtures for site application. Table (4) below shows the prepared mixtures and proportions.

\section{RESULTS AND DISCUSSIONS}

The historical mortars at Qasr Tuba show significant differences in terms of bending materials and in the way of application. The most important feature of Qasr Tuba is the use of the lime-based mortar in addition to the gypsum-lime based mortar. The lime-based mortar consists of heavily deteriorated greyish lime mortar with charcoal, sandstone, and rock aggregate admixture, which was used as embedding mortars for foundation and joint mortars in the lowest parts of the building walls. Rock aggregates were collected from the closest wadi. Furthermore, the gypsum-lime mortar consists of the fresh gypsum-lime mortar with admixture of grog and sandstone as well as low rock aggregate and charcoal content that has been used as joint mortars in the upper parts of the building walls for baked bricks.

Omeri (2009) reported that different functions determined the choice of the binding medium. Lime was used within the lowest parts of walls and potentially moist parts of the structure or at the sides that are exposed to heavy rain. The analysis of the mortar samples for mineralogical composition identification was completed using different analytical techniques for comparison and assurance as well as to rebuild a clear image of the original mortar formulation. Optical microscopy (OM) of thin sections was the first method of analysis applied to the Qasr Tuba mortar samples. On the basis of the petrographic study of JMUP (Fig. 3 and Table 5), the cement material was a mixture of hydrated and

Table 4. Mixtures Proportions.

\begin{tabular}{|c|c|c|c|c|c|c|c|c|c|c|}
\hline $\begin{array}{l}\text { Mix. } \\
\text { No. }\end{array}$ & $\begin{array}{l}\text { Free } \\
\text { Water } \\
\text { (g) }\end{array}$ & $\begin{array}{c}\mathrm{NaOH} \\
(\mathrm{g})\end{array}$ & $\begin{array}{l}\text { Sand } \\
(\mathrm{g})\end{array}$ & $\begin{array}{c}\text { Limestone } \\
2 \mathrm{~mm} \\
(\mathrm{~g})\end{array}$ & $\begin{array}{c}\text { Limestone } \\
8 \mathrm{~mm} \\
(\mathrm{~g})\end{array}$ & $\begin{array}{c}\text { Grog } \\
\text { (g) }\end{array}$ & $\begin{array}{l}\text { Lime } \\
\text { Putty } \\
\text { (g) }\end{array}$ & $\begin{array}{l}\text { Ash } \\
(g)\end{array}$ & Gypsum (g) & Straw (g) \\
\hline $\mathrm{H} 1$ & 60 & 6.0 & 450 & 300 & 1050 & 300 & 1800 & -- & -- & -- \\
\hline $\mathrm{H} 2$ & 60 & 6.0 & 450 & 300 & 1050 & 300 & 1800 & -- & -- & -- \\
\hline $\mathrm{H} 3$ & 60 & 9.0 & 300 & -- & 1350 & 450 & 1800 & -- & -- & -- \\
\hline $\mathrm{H} 4$ & 60 & 6.0 & 450 & 240 & 1050 & 300 & 1800 & -- & 60 & -- \\
\hline $\mathrm{H} 5$ & 60 & 6.0 & 360 & 240 & 1050 & 300 & 1800 & -- & 150 & - \\
\hline $\mathrm{H} 6$ & 60 & 7.2 & 360 & 240 & 1050 & 360 & 1800 & -- & 90 & -- \\
\hline $\mathrm{H} 7$ & 210 & 7.2 & 750 & 900 & -- & 360 & 1800 & -- & 90 & -- \\
\hline $\mathrm{H} 8$ & 60 & -- & 360 & 240 & 1050 & 360 & 1800 & 7.2 & 90 & -- \\
\hline $\mathrm{H} 9$ & 210 & -- & 750 & 900 & -- & 360 & 1800 & 7.2 & 90 & -- \\
\hline $\mathrm{H} 10$ & 60 & -- & 380 & 270 & 1050 & 400 & 1800 & 8 & -- & -- \\
\hline $\mathrm{H} 11$ & 210 & -- & 800 & 900 & -- & 400 & 1800 & 8 & -- & 9 \\
\hline $\mathrm{H} 12$ & 60 & -- & 380 & 270 & 1050 & 400 & 1800 & 8 & -- & 9 \\
\hline \multicolumn{11}{|c|}{$\begin{array}{l}\text { Notes: } \\
\text { (H1): Coarse mix with coarse aggregate. } \\
\text { (H2): Same as H1, but Swealeh sand and Limestone powder below sieve No.100 was removed. } \\
\text { (H3): Same as H2, but without Limestone powder and with more Semsmyeh, Grog and NaOH. } \\
\text { (H4): Same as H2, but Gypsum was added, and Limestone was reduced. } \\
\text { (H5): Same as H4, but Gypsum was increased, and Sand was reduced. } \\
\text { (H6): Same as H1, but Gypsum was added, Limestone and sand were reduced, and Grog and NaOH was increased. } \\
\text { (H7): Fine mix without coarse aggregate. } \\
\text { (H8): Same as H6, but with Ash instead of NaOH. } \\
\text { (H9): Same as H7, but with Ash instead of NaOH. } \\
\text { (H10): Same as H8, but without Gypsum. } \\
\text { (H11): Fine mix, with Straw and without Gypsum. } \\
\text { (H12): Coarse mix, with Straw and without Gypsum. }\end{array}$} \\
\hline
\end{tabular}


anhydrate gypsum (around 50-60\%) and slaked lime (around 10-20\%). The rest of the content was sandstone, grog, rock fragments, and small amounts of plant remains ash. The presence of grog gives the red or flesh color to the mortar. Moreover, the iron oxide that is associated with clay minerals gave the color to the grog during the preparation process.

On the basis of the petrographic study of JMLP (Fig. 4 and Table 6), the cement material was a mixture of slaked lime (around 30-40\%) as well as hydrated and anhydrate gypsum (around $5-10 \%$ ). The rest of content was sandstone, grog and rock fragments as well as plant remains ash. The presence of plant remains ash and coal give the grey color to JMLP.

In this study, the XRD patterns reveal that the pozzolanic reaction of calcium hydroxide with metakaolinite produced calcium silicate hydrate (C-S-H) in the form of $5 \mathrm{CaSiO}_{3} \cdot \mathrm{H}_{2} \mathrm{O}$ (Xonotlite) at $2 \Theta$ peaks 29.06, 31.70 and 36.04 (Fig. 5). In addition, another pozzolanic product was formed in the form of calcium aluminum silicate hydrate (C-A-S-H) $\left(\mathrm{Ca}_{2} \mathrm{Al}_{2} \mathrm{SiO}_{7} .8 \mathrm{H}_{2} \mathrm{O}\right.$ (Stratlingite)) at $2 \Theta$ peaks $31.06,35.92$, and 48.40 . It was found that the Calcium Aluminum hydrate $(\mathrm{C}-\mathrm{A}-\mathrm{H})$ appeared in the XRD pattern of JMUP at $2 \Theta$ peaks $20.68,31.06,33.31$, and 35.92. This result is in line with Murat (1983). Moreover, Frías Rojas and Cabrera (2002) compared the reaction of 1:1 hydrated lime to metakaolin blends at 23 and $60^{\circ} \mathrm{C}$. They found that cementitious materials in the form of calcium aluminum silicate hydrates were formed. C2ASH8 (stratlingite) and C4AH13 appeared at room temperature, whereas $\mathrm{C} 3 \mathrm{ASH} 6$ (hydrogarnet) was obtained at high temperature.
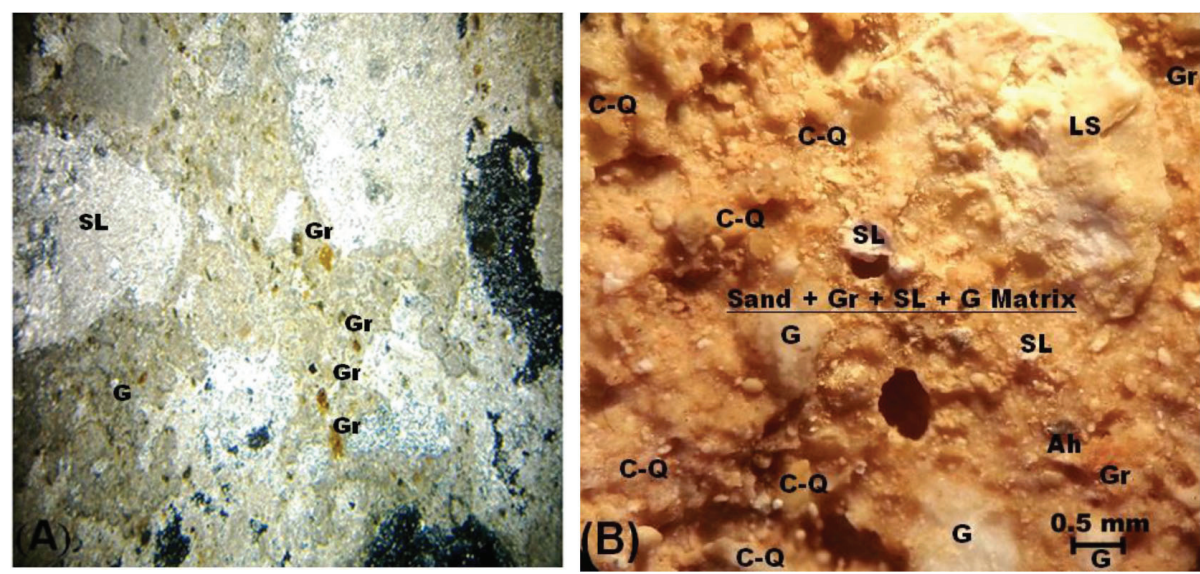

Figure 3. Microscopic images of joint mortar for baked bricks at upper part of walls in Qasr Tuba.

(A) Polarized optical microscope photo X40 XPL of thin section. (B) Stereoscopic optical microscope Photo X14. The matrix consists of a mixture of slaked lime (SL) and gypsum (G) as cement material and sandstone, as well as coarse quartz (C-Q) with little amount of rock aggregates.
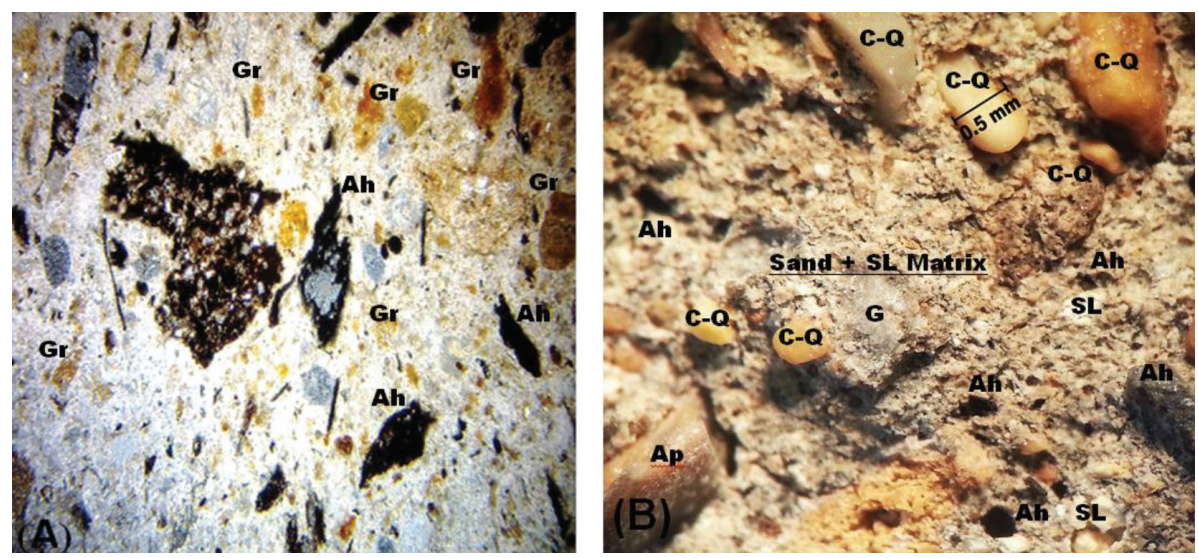

Figure 4. Microscopic images of mortar which were used as embedding mortar for foundation and as joint mortar for building limestone at lower part of walls in Qasr Tuba. (A) Polarized optical microscope photo X40 XPL of thin section. (B) Stereoscopic optical microscope Photo. The matrix consists of slaked lime (SL), sandstone, plant remains ash (Ah) and different rock aggregates such as Apatite (Ap) and course quartz (C-Q). 
Table 5. Mortar composition and description for Qasr Tuba from the upper part of the wall.

\begin{tabular}{|l|c|c|}
\hline \multicolumn{1}{|c|}{ Component } & Abundance $\%$ & Description \\
\hline Limestone Fragments & 16 & Very fine micritic L.St, almost less than 0.2 mm in diameter \\
\hline Sand Grains (Quartz) & 01 & \\
\hline Slaked Lime & 58 & \\
\hline Crushed Fired Bricks & 04 & $\begin{array}{c}\text { Irregular grains with no definite grain boundaries, their relative } \\
\text { high interference color of second and third order indicates its } \\
\text { transformation into anhydrous phase of Gypsum (Anhydrite) }\end{array}$ \\
\hline Gypsum & 20 & \\
\hline Chert & -- & General Notes: Compacted \\
\hline Plant Remains/ Coal & 01 & \multicolumn{2}{|c|}{} \\
\hline \multicolumn{2}{|c|}{} \\
\hline
\end{tabular}

Table 6. Mortar Composition and description for Qasr Tuba from the foundation and lower part of walls

\begin{tabular}{|l|c|c|}
\hline \multicolumn{1}{|c|}{ Component } & Abundance \% & Description \\
\hline Limestone Fragments & 12 & $\begin{array}{c}\text { Very fine micritic L.St., some grains show recrystallization } \\
\text { and therefore it has polygonal structure }\end{array}$ \\
\hline Sand Grains (Quartz) & 02 & \begin{tabular}{c} 
Very fine silt sized \\
\hline Slaked Lime
\end{tabular} \\
\hline Crushed Fired Bricks & 20 & $\begin{array}{c}\text { Occurs as massive matrix binding all components } \\
\text { together. It reacts with HCl }\end{array}$ \\
\hline Gypsum & 01 & Varies in size from 0.05 to $1.00 \mathrm{~mm}$ \\
\hline Chert & -- & Black and brown color, some have internal biogenic plant structure \\
\hline Plant Remains/ Coal & 12 & General Notes: It has compacted structure without voids or cracks \\
\hline \multicolumn{2}{|c|}{}
\end{tabular}

(A)

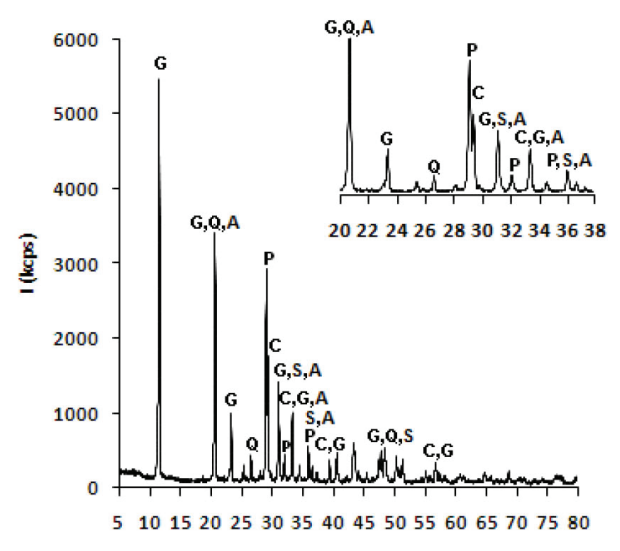

$2 \theta$
(B)

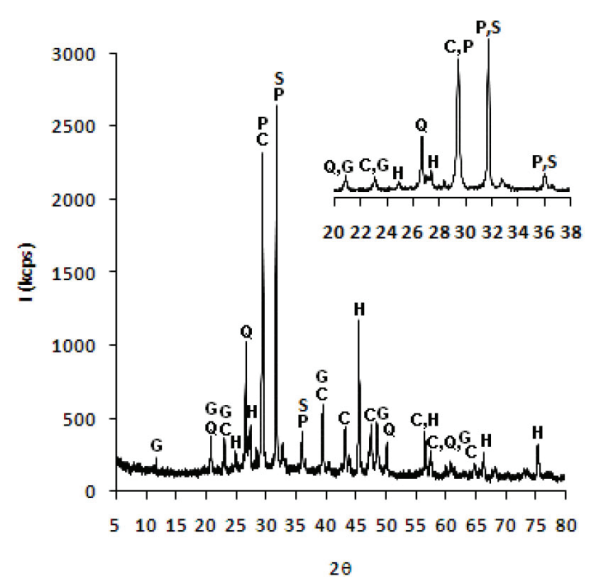

Figure 5. XRD Spectra for the mortar samples from Al-Tuba castle (A) joint mortar for building baked bricks at upper part of wall (B) mortar which have been used as embedding mortar for foundation and as joint mortar for building limestone at the lower part of walls. Where C: Calcite, H: Halite, Q: Quartz, G: Gypsum and P: Pozzolanic product (Calcium silicate hydrate), S: Pozzolanic product (Calcium Aluminum silicate hydrate) and A: Pozzolanic product (Calcium Aluminum hydrate).

\section{Pozzolanic Reactions}

The hydraulic lime (calcium hydroxide) mortars solidify by carbonation via the conversion of calcium hydroxide to calcium carbonate through reaction with carbon dioxide $\left(\mathrm{CO}_{2}\right)$ in the atmosphere (Eckel, 2017). Therefore, using the hydraulic lime mortar is considered as building an environment for sequestering the $\mathrm{CO}_{2}$ gas, which has a direct impact on global 
warming. Moreover, a significant reduction in $\mathrm{CO}_{2}$ up to 225,000 tons would be achieved, if lime was used (Harrison, 2005).

The materials that prompt hydraulic lime mortars to set rapidly are known as 'pozzolans'. According to ASTM (C618), pozzolan is defined as a siliceous and aluminous material that reacts chemically with calcium hydroxide in the presence of moisture at room temperature to form cementitious material. Naturally, pozzolans are formed from the volcanic ejection material such as scoria and pumice or volcanic tuff. Moreover, metakaolin is a pozzolanic material derived from brick dust from clay bricks fired at less than $950^{\circ} \mathrm{C}$ and crushed fired-clay products (metakaolin), such as rejected clay tile or brick (Rao, 2003; Gibbons, 1997; Zampieri, 1990; Murat, 1983).

Metakaolin is a pozzolanic material too. It is obtained by calcination of kaolinitic clay at temperatures ranging from 700 to $800{ }^{\circ} \mathrm{C}$ (Equation 2) (Zampieri, 1990).

$$
\begin{aligned}
& \mathrm{Al}_{2} \mathrm{Si}_{2} \mathrm{O}_{5}(\mathrm{OH}) 4 \stackrel{700-800{ }^{\circ} \mathrm{C}}{\longrightarrow} \mathrm{Al}_{2} \mathrm{O}_{3} \cdot 2 \mathrm{SiO}_{2}+2 \mathrm{H}_{2} \mathrm{O} \\
& \text { Kaolin Metakaolin }
\end{aligned}
$$

The hydration reaction of metakaolin takes place at environmental temperature. The hydrated products from reaction of metakaolin with calcium hydroxide are shown by Murat (1983) (Equation 3).

$$
\begin{aligned}
& \text { Metakaolin }+ \text { Calcium Hydroxide } \longrightarrow \\
& + \text { Water } \\
& \text { Calcium Aluminum hydrate }(C-A-H) \\
& + \text { Calcium silicate hydrate }(C-S-H) \\
& + \text { Calcium Aluminum silicate hydrate }(C-A-S-H)
\end{aligned}
$$

\section{Fourier transform infrared spectroscopy (FTIR)}

FTIR has been applied for the determination of hydration products in modern cement (Henning, O. 1974). FTIR has also been used to distinguish the varieties of opal (non-crystalline silica), quartz, Kaolinite, calcite, dolomite mica, and halide salts (Kourti et al., 2010; Rice et al., 1995; Van der Marel and Beutelspacher, 1976).

The comparison of the FTIR spectra revealed similarities between the mortar samples from the Al-Tuba castle samples. JMUP and JMLP show that the mortar samples contain appreciable amounts of calcite, quartz, meta-kaolinite (in the form of grog), organic matter (woods and plants remain ash), chlorite, and water as well as gypsum. Moreover, JMUP contains more gypsum than JMLP. This was proven through the analysis of the same samples by XRD and XRF as shown below.

One possible explanation for the existence of chloride is that the summer season is hot enough to accumulate salts by evaporation of humidity stored in the wall during the raining season and/ or wadi surface runoff. In addition, chloride salts significantly contribute to the wind-blown dust across the desert in the summer and fall. This is in agreement with the previous studies which were carried on the Nabatean mortars in Petra (Omeri, 2009)

On the basis of the standard meta-kaolinite FTIR spectrum that was prepared in this study, the meta-kaolinite, which can be considered as grog, has a main peak in the region between $1026.13-1180.43 \mathrm{~cm}^{-1}$ for Si-O-Si. Moreover, it has Si-O bending vibrational band at 466.77 and $694.23 \mathrm{~cm}^{-1}$ as well as Si-O-Al stretching vibrational band at $798.53 \mathrm{~cm}^{-1}$. Furthermore, Al-OH inner peak between 3020 and $3749 \mathrm{~cm}^{-1}$ is absent. According to Kourti et al. (2010) and Van der Marel and Beutelspacher (1976), kaolinite has Si-O bending vibrational band at 420 and $460 \mathrm{~cm}^{-1}$ as well as Si-O-Al stretching vibrational band at $711.23 \mathrm{~cm}^{-1}$. In addition, it has a very intense Si$\mathrm{O}-\mathrm{Si}$ peak at $1032.75 \mathrm{~cm}^{-1}$ and $\mathrm{Al}-\mathrm{OH}$ inner peak at $3618.87 \mathrm{~cm}^{-1}$. Therefore, the absence of Al-OH inner peak from the investigated samples is a satisfactory indication that the mortar samples contain meta-kaolinite rather than kaolinite. This result is in agreement with the results revealed from the XRD pattern which confirmed the absence of kaolinite.

The FT-IR spectrum of the JMUP and JMLP samples displays different common organic characteristic bands (Fig. 6). The main broad $\mathrm{O}-\mathrm{H}$ stretch band at $3356.73,3456.43 \mathrm{~cm}^{-1}$. Another O-H stretching peak observed at 2526.75 , $2522.89 \mathrm{~cm}^{-1}$ for carboxylic acid compounds in mortar samples. The transition band was observed at $2951.09,2912.51 \mathrm{~cm}^{-1}$ in a JMLP sample ascribing to the $\mathrm{C}-\mathrm{H}$ stretching, with different substituted bending-vibration peaks at 871.80 and $856.4 \mathrm{~cm}^{-1}$ for alkanes and alkenes structures, respectively. JMUP and JMLP have many isolated and conjugated compounds that contain different types of double bonds bands at 11805.37, 1801.51, 1693.50, and $1743.65 \mathrm{~cm}^{-1}$ for $\mathrm{C}=\mathrm{O}$, 1624.06 and 1639.49 for $\mathrm{C}=\mathrm{C}$ stretching. The 
FT-IR measurement shows that JMLP has higher organic matter (plant remains ash), chloride salt and water content than JMUP.

Thermal gravimetric analysis (TGA) was carried out to determine the sample loses at different temperatures of mortar samples from the Al-Tuba castle under the open atmosphere condition. The weight loss of the sample indicates the fraction of a sample that been decomposed during the process (Samtani et al., 1996). The sample pattern obtained from the thermal gravimetric analysis of mortar samples provides qualitative information about the thermal reaction processes by using the oven methodology.

The TGA curve of the mortar samples (Fig. 7) show that there is residual humidity (free water) of mass loss at $105^{\circ} \mathrm{C}$ characterized by a drop-in weight of $0.9 \%$ and $5.6 \%$ for JMUP and JMLP, respectively. There is a significant mass loss until $250^{\circ} \mathrm{C}$ by $9.9 \%$ and $5.2 \%$ for JMUP and JMLP, respectively. At this step, the loss was characterized by crystalline bound water (dehydration) and some low temperature organic volatiles. In a comparison between JMUP and JMLP, the mass loss until $250^{\circ} \mathrm{C}$ was higher in JMUP. One possible explanation is dehydration of gypsum, which represents part of the cement material in JMUP. There is no significant difference in mass loss occurring from $250^{\circ} \mathrm{C}$ to $500^{\circ} \mathrm{C}$ between JMUP and JMLP. During this step, almost total combustion of any carbonaceous organic compounds occurs, which are mainly derived from plant and animal remains in the mortar samples. A second significant drop, which ends at $750^{\circ} \mathrm{C}$, is characterized by mass loss of $6.4 \%$ and $16.7 \%$ for JMUP and JMLP, respectively. This is primarily due to dehydroxilation of the hydraulic lime $\left(\mathrm{Ca}(\mathrm{OH})_{2}\right)$ and combustion of any residual carbonaceous organic compounds decomposition of the present mortar samples. Dabiri et al. (2010) reported that dehydroxilation occurs at about $550^{\circ} \mathrm{C}$ to $700^{\circ} \mathrm{C}$. Finally, as the temperatures increase between $700^{\circ} \mathrm{C}$ to $900^{\circ} \mathrm{C}$, a mass loss of $0.9 \%$ and $2.3 \%$ for JMUP and JMLP is observed, respectively. This is mainly due to calcination and residual dehydroxilation. At this step, decomposition of carbonates with the formation of oxides and carbon dioxide occurs. The most notable metal oxide of all formed by these reactions is calcium oxide $(\mathrm{CaO})$, which is formed from the calcium minerals present in the mortar in the form of calcite $\left(\mathrm{CaCO}_{3}\right)$. The sample weight seemed to be constant after the temperature reaches $850^{\circ} \mathrm{C}$. It indicates that the process was already completed, and the sample left is recognized as 'ash' (Levienspiel, 1999). The TGA analyses of the mortar samples give good indication that the cement material that has been used in the JMUP was a blind of hydraulic lime and gypsum while in the JMLP was only hydraulic lime.

Material balances are an important step when designing a new mortar mixture or reverse engineering and analyzing an original historical mortar. Material balances involve the application of the law of conservation of mass, which states that mass can neither be created nor destroyed. Thus, total mass of input (oxides $\%$ ) = total mass of output (minerals \%). The quantitative chemical analysis provides the basic information of the atomic formula of a mineral (Dana, 1985).

The quantitative minerals content was recalculated for the JMUP and JMLP samples based
(A)

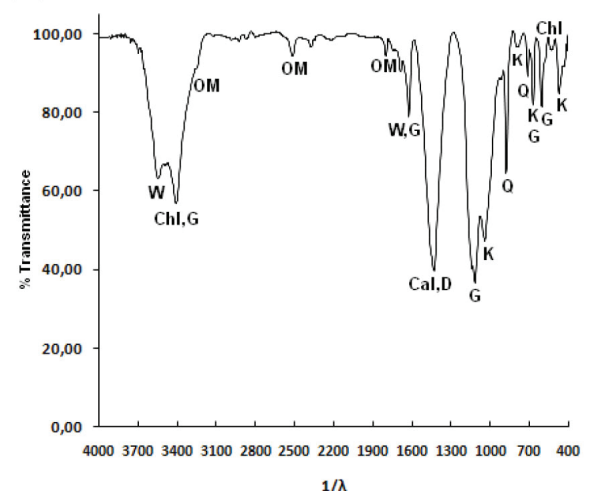

(B)

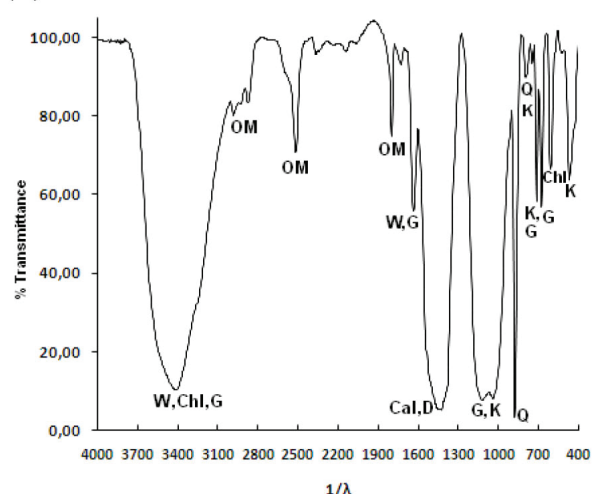

$1 / \lambda$

Figure 6. FTIR Spectra for the mortar samples from Al-Tuba castle (A) joint mortar for building baked bricks at upper part of walls (B) mortar which were used as embedding mortar for foundation and as joint mortar for building limestone at lower part of walls. Where Cal: calcite, Chl: chlorite,

D: dolomite, K: meta-kaolinite, G: gypsum, Q: quartz, OM: organic matter and W: water. 
(A)

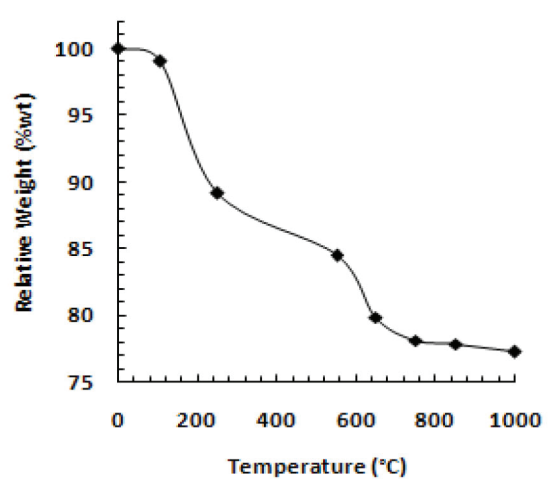

(B)

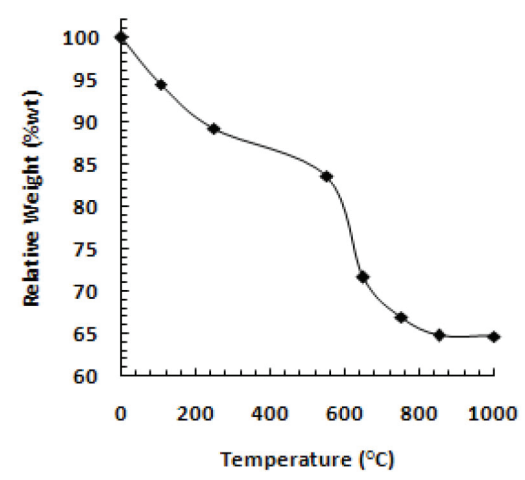

Figure 7. Thermal gravimetric analysis (TGA) curve for mortar samples from the Al-Tuba castle at various temperatures from ambient to $1000^{\circ} \mathrm{C}$ (A) joint mortar for building baked bricks at upper part of walls (B) mortar which was used as embedding mortar for foundation and as joint mortar for building limestone at lower part of walls.

on material balance (Table 8), the results of the chemical analysis of the JMUP and JMLP samples (Table 7), the mineral quality by the X-ray diffraction patterns (Fig. 5), FTIR spectrum (Fig. 6), and TGA curve (Fig. 7) as well as polarized and stereoscopic microscope images (Fig. 3 and Fig. 4). The results of the quantitative and qualitative were in agreement and supported each other. The JMUP sample represents the highest gypsum content and lowest quartz content. Furthermore, the gypsum - hydrated lime ratio was 4:1.It has a reddish color due to the iron oxide content, which is associated with grog (metakaolinite). The JMLP sample represents the highest hydrated lime content. The gypsum - hydrated lime ratio was 1:3. In comparison to the aggregates content, the JMLP has a high content of calcite, apatite, quartz and

Table 7. Chemical analyses of total major elemental composition and major acid soluble elements for the historical mortar and plaster samples

\begin{tabular}{|c|c|c|c|c|}
\hline Specification & \multicolumn{2}{|c|}{$\begin{array}{c}\text { Total major } \\
\text { oxides }\end{array}$} & \multicolumn{2}{c|}{$\begin{array}{c}\text { Major acid soluble } \\
\text { oxides }\end{array}$} \\
\hline Oxide & $\begin{array}{c}\mathrm{JMUP} \\
(\%)\end{array}$ & $\begin{array}{c}\mathrm{JMLP} \\
(\%)\end{array}$ & $\begin{array}{c}\text { JMUP } \\
(\%)\end{array}$ & $\begin{array}{c}\text { JMLP } \\
(\%)\end{array}$ \\
\hline $\mathrm{SiO}_{2}$ & 7.06 & 19.11 & 0.02 & 0.02 \\
\hline $\mathrm{Al}_{2} \mathrm{O}_{3}$ & 1.19 & 2.10 & 0.45 & 0.95 \\
\hline $\mathrm{Fe}_{2} \mathrm{O}_{3}$ & 0.48 & 0.91 & 0.33 & 0.82 \\
\hline $\mathrm{TiO}_{2}$ & 0.09 & 0.19 & --- & --- \\
\hline $\mathrm{P}_{2} \mathrm{O}_{5}$ & 1.86 & 1.13 & --- & --- \\
\hline $\mathrm{CaO}$ & 34.24 & 32.78 & 34.24 & 28.32 \\
\hline $\mathrm{MgO}_{\mathrm{Na}} \mathrm{O}$ & 0.56 & 1.23 & 0.56 & 1.23 \\
\hline $\mathrm{Na}_{2} \mathrm{O}$ & 0.06 & 0.00 & 0.06 & 0.00 \\
\hline $\mathrm{SO}_{4}$ & 0.13 & 1.35 & 0.09 & 0.00 \\
\hline
\end{tabular}

plant remains (coal) up to $16.19,2.55,14.97$, and $10.99 \%$, respectively. In comparison to the results of material balances with X-ray diffraction patterns, the XRD patterns reveal the absence of metakaolinite, rutile, Hematite, alumina, and ash while the chemical analysis and quantitative minerals calculation shows that these minerals are present. This could be attributed to the fact XRD cannot detect the amorphous material. Moreover, the mineral content which is less than $3 \%$ is under the detection limit of X-ray diffraction.

Table 8. Material balanced analyses were recalculated based on the major elements chemical analysis data, XRD results, FTIR spectra, thermal gravimetric analysis (TGA) curve and the petrographic analysis under stereo-microscope as well as polarized-microscope for the historical mortar samples from Qasr Tuba

\begin{tabular}{|l|c|c|}
\hline \multicolumn{1}{|c|}{ Mineral content } & $\begin{array}{c}\text { JMUP } \\
(\%)\end{array}$ & $\begin{array}{c}\text { JMLP } \\
(\%)\end{array}$ \\
\hline Quartz $\left(\mathrm{SiO}_{2}\right)$ & 4.10 & 14.97 \\
\hline Metakaolinite $\left(\mathrm{Al}_{2} \mathrm{Si}_{2} \mathrm{O}_{5}\right)$ & 1.63 & 2.53 \\
\hline Calcium silicate hydrate $(\mathrm{C}-\mathrm{S}-\mathrm{H})$ & 4.14 & 9.51 \\
\hline Lime $(\mathrm{CaO})$ & 1.90 & 1.24 \\
\hline Calcite $\left(\mathrm{CaCO}_{3}\right)$ & 5.91 & 16.19 \\
\hline Apatite $\left(\mathrm{Ca}_{3}\left(\mathrm{PO}_{4}\right)_{2}\right)$ & 4.06 & 2.55 \\
\hline Gypsum $\left(\mathrm{CaSO}_{4} \cdot 2 \mathrm{H}_{2} \mathrm{O}\right)$ & 55.97 & 7.64 \\
\hline Hydrated lime $\left(\mathrm{Ca}(\mathrm{OH})_{2}\right)$ & 13.86 & 21.52 \\
\hline Organic $\mathrm{Matter}(\mathrm{plant}$ remains $))$ & 4.66 & 10.99 \\
\hline Humidity & 0.91 & 5.76 \\
\hline Ash $\left(\mathrm{NaO}+\mathrm{K}_{2} \mathrm{O}+\mathrm{MgO}\right)$ & 0.28 & 2.65 \\
\hline Alumina $\left(\mathrm{Al}_{2} \mathrm{O}_{3}\right)$ & 0.45 & 0.98 \\
\hline Hematite $\left(\mathrm{Fe}_{2} \mathrm{O}_{3}\right)$ & 0.48 & 0.94 \\
\hline Rutile $\left(\mathrm{TiO}_{2}\right)$ & 0.09 & 0.19 \\
\hline \%Total & 98.44 & 97.66 \\
\hline
\end{tabular}




\section{Mixtures results}

At the beginning, the mixtures from $\mathrm{H} 1$ to $\mathrm{H} 7$ were prepared. The behavior at fresh state was observed, while the properties at the hardened state were tested. Afterwards, different modifications and trials were conducted in order to obtain the required results. Table (9) below shows these results. Compressive strength, flexural strength, and bond strength tests were conducted at age of 28 days according to the European-Jordanian Standard (BS EN 998:2003, JS 10036:2007). The proportions and components of mixtures were modified according to the initial results obtained for both coarse and fine mixtures.

\section{CONCLUSIONS AND RECOMMENDATIONS}

Two types of mortar were used in Qasr Tuba: (i) lime-based mortar was used for foundation and joint mortars in the lower parts of the building walls at gypsum - hydrated lime ratio of 1:3; and (ii) The gypsum-based mortar was used as joint mortars in the upper parts of the building's walls for baked bricks at the gypsum - hydrated lime ratio of $4: 1$. In addition, the pozzolanic reaction in the Qasr Tuba mortar produced a new formation of $5 \mathrm{CaSiO}_{3} \cdot \mathrm{H}_{2} \mathrm{O}$ (Xonotlite), $\mathrm{Ca}_{2} \mathrm{Al}_{2} \mathrm{SiO}_{7} \cdot 8 \mathrm{H}_{2} \mathrm{O}$ (Stratlingite) and calcium aluminum hydrate as a secondary cementing mineral.

According to the results of both fresh and hardened states, the following conclusions can be drawn: $\mathrm{NaOH}$ cannot be used in any of the coarse or fine mixes due to the white appearance on the material surface. The gypsum addition with a certain amount can enhance mixed cohesion at a fresh state and reduce the crack appearance at the hardened state. The addition of straw to both types of mortar (coarse and fine) can reduce the appearance of the cracks and, as a result, increase the mortar durability. Only the mixes from H8 to $\mathrm{H} 12$ can be used at the site with special consideration. The flexural strength, compressive strength, and tensile adhesion strength for mixes (H8, H9, H10, H11, H12) were very good values for the no-cement mixes and above expectations.

In conclusion, using the hydraulic lime mortar is considered as building an environment for capturing the $\mathrm{CO}_{2}$ gas. Therefore, developing the codes of practice and disseminating results is a rational action. In addition, the following recommendations should be highly considered when working at the site:

Table 9. Results obtained for the considered mixtures.

\begin{tabular}{|c|c|c|c|c|c|}
\hline $\begin{array}{l}\text { Mix. } \\
\text { Name }\end{array}$ & Fresh State Observations & Hardened State Observations & $\begin{array}{l}\text { Compressive } \\
\text { Strength } \\
\text { (MPa) }\end{array}$ & $\begin{array}{c}\text { Flexural } \\
\text { Strength } \\
(\mathrm{MPa})\end{array}$ & $\begin{array}{l}\text { Bond } \\
\text { Strength } \\
\text { (MPa) }\end{array}$ \\
\hline $\mathrm{H} 1$ & $\begin{array}{l}\text { Coarse agg. amount was less } \\
\text { than that of original samples. }\end{array}$ & $\begin{array}{l}\text {-White appearance at samples surfaces. } \\
\text {-A lot of cracks. }\end{array}$ & 0.3 & 1.2 & $\begin{array}{c}\text { Not } \\
\text { Applicable }\end{array}$ \\
\hline $\mathrm{H} 2$ & $\begin{array}{l}\text { Coarse agg. amount was } \\
\text { acceptable. }\end{array}$ & $\begin{array}{c}\text { White appearance at samples surfaces. } \\
\text {-A lot of cracks but less than } \mathrm{H} 1 \text {. }\end{array}$ & 0.4 & 1.0 & $\begin{array}{c}\text { Not } \\
\text { Applicable }\end{array}$ \\
\hline $\mathrm{H} 3$ & $\begin{array}{l}\text { Coarse agg. amount was } \\
\text { acceptable. }\end{array}$ & $\begin{array}{l}\text {-White appearance at samples surfaces. } \\
\text {-A lot of cracks. }\end{array}$ & 0.3 & 0.7 & $\begin{array}{c}\text { Not } \\
\text { Applicable }\end{array}$ \\
\hline $\mathrm{H} 4$ & $\begin{array}{l}\text { More cohesion between mix } \\
\text { components. }\end{array}$ & $\begin{array}{l}\text {-White appearance at samples surfaces. } \\
\text {-Less cracks. }\end{array}$ & 0.8 & 1.0 & $\begin{array}{c}\text { Not } \\
\text { Applicable }\end{array}$ \\
\hline H5 & $\begin{array}{l}\text { Workability decreased with } \\
\text { time, low workability. }\end{array}$ & $\begin{array}{l}\text {-White appearance at samples surfaces. } \\
\text {-Hairy cracks. }\end{array}$ & 0.7 & 1.5 & $\begin{array}{c}\text { Not } \\
\text { Applicable }\end{array}$ \\
\hline $\mathrm{H} 6$ & $\begin{array}{l}\text { Good workability and good } \\
\text { cohesion. }\end{array}$ & $\begin{array}{l}\text {-White appearance at samples surfaces. } \\
\text {-Hairy cracks. }\end{array}$ & 0.8 & 1.2 & $\begin{array}{c}\text { Not } \\
\text { Applicable }\end{array}$ \\
\hline $\mathrm{H} 7$ & $\begin{array}{l}\text { Good workability and good } \\
\text { cohesion. }\end{array}$ & $\begin{array}{l}\text { White appearance at samples surfaces. } \\
\text {-Hairy cracks. }\end{array}$ & 0.9 & 1.9 & $\begin{array}{c}\text { Not } \\
\text { Applicable }\end{array}$ \\
\hline $\mathrm{H} 8$ & $\begin{array}{l}\text { Good workability and good } \\
\text { cohesion. }\end{array}$ & $\begin{array}{c}\text { - No white appearance. } \\
\text {-Hairy cracks. }\end{array}$ & 0.6 & 2.3 & 0.5 \\
\hline $\mathrm{H} 9$ & $\begin{array}{c}\text { Good workability and good } \\
\text { cohesion. }\end{array}$ & $\begin{array}{c}\text { - No white appearance. } \\
\text {-Hairy cracks. }\end{array}$ & 0.6 & 2.3 & 0.6 \\
\hline H10 & $\begin{array}{l}\text { Good workability and good } \\
\text { cohesion. }\end{array}$ & $\begin{array}{c}\text { - No white appearance. } \\
\text {-Hairy cracks. }\end{array}$ & 0.8 & 2.6 & 0.5 \\
\hline $\mathrm{H} 11$ & $\begin{array}{c}\text { Good workability and good } \\
\text { cohesion. }\end{array}$ & $\begin{array}{c}\text { - No white appearance. } \\
\text {-No cracks. }\end{array}$ & 1.1 & 1.3 & 0.6 \\
\hline $\mathrm{H} 12$ & $\begin{array}{l}\text { Good workability and good } \\
\text { cohesion. }\end{array}$ & $\begin{array}{l}\text { - No white appearance. } \\
\text {-No cracks. }\end{array}$ & 0.9 & 1.3 & 0.6 \\
\hline
\end{tabular}


- All fine materials below sieve no. 100 should be removed from the mixed compositions.

- Fine aggregate grading should be within the acceptable ranges given in Jordanian standards. Any changes can highly affect the mix performance.

- Aggregate moisture content should be considered during site mixing, since any increase in the water amount will reduce the mortar strength.

- A brick must be soaked in water to saturation before mortar application.

- It is recommended to make trial mixtures from the materials available in the project site, to make sure that mortar performance is the same as the mixes prepared in the lab, otherwise, some modifications may be required.

\section{Acknowledgments}

The authors would like to express thanks to the Royal Scientific society (RSS), Al-Balqa Applied University and Royal Botanic Gardin $(R B G)$ for the support and provision of the research facilities. The authors acknowledge Mr. Kyle Cordova for text editing and improving, Dr. Adeeb Abushmais from the Friends of Archaeology and Heritage (FOAH) and Mr. Amer Souleman for assistance provided during samples collection and fieldwork. Many thanks go to Eng. Shahrazad Ghreir / Architect at Greater Amman Municipality for re-draw the plan of Qasr Tuba, Jordan Desert Castles.

\section{REFERENCES}

1. Al-Hiyari, A. and Halasa, W. 2009. Map of Qasr atTuba, Geological Mapping Division Natural mapping project, Amman: Natural Resources Authority.

2. Chierici, G.L. 1994. The Material Balance Equation. In Principles of Petroleum Reservoir Engineering, edited by G.L. Chierici, 359-404. Berlin, Heidelberg: Springer. https://doi. org/10.1007/978-3-662-02964-0_10.

3. Creswell, K. 1979. Early Muslim Architecture. Vol. I, part. II, New York: Hacker Art Books.

4. Dabiri, R., Mollaei, H., Ghaffari, M., Golizadeh, K. 2010. Synthesis Process of Forsterite Refractory by Natural Serpentine. The 1st International Applied Geological Congress, Department of Geology, Iran: Islamic Azad University - Mashad Branch, April 26-28.

5. Dana, J.D. 1985. Manual of mineralogy. 20th edition, New York: Jonh Wiley\& Sons.
6. Eckel, E.C. 2017. Cements, Lime and Plaster: Their Materials, Manufacture and Properties. 16th Edition, London: Forgotten Books.

7. Elmeligy, D. 2016. Biomimicry for Ecologically Sustainable Design in Architecture: A Proposed Methodological Study. Proceeding of the 6th International Conference on Harmonisation between Architecture and Nature, 45-57. Alicante: WIT Press. Doi:10.2495/ARC160051.

8. Frías Rojas, M., and Cabrera. J. 2002. The Effect of Temperature on the Hydration Rate and Stability of the Hydration Phases of Metakaolin -lime-water Systems. Cement and Concrete Research 32, no. 1 133-138.

9. Ghirshman, R. Iran: From the Earliest Times to the Islamic Conquest. Harmondsworth, Middlesex: Penguin Books, 1954.

10. Gibbons, P. 1997. Pozzolans for Lime Mortars. The Conservation and Repair of Ecclesiastical Buildings. Tisbury: Cathedral Communications Limited. http://www.buildingconservation.com/articles/ pozzo/pozzo.htm.

11. Groot, C.J.W.P., and. Gunneweg, J.T.M. 2019. Choosing Mortar Compositions for Repointing of Historic Masonry Under Severe Environmental Conditions. In: Historic Mortars, edited by J. Hughes, J. Válek J., and C. Groot, 143-154. Cham: Springer, https://doi.org/10.1007/978-3-319-91606-4_11.

12. Harrison, J. 2005. Carbonating and Hydraulic Mortars: The Difference is Not Only in the Binder, Aggregates are also Important. 10th Canadian Masonry Symposium, Banff, Alberta, June 8-12. http:// canadamasonrydesigncentre.com/download/10th symposium/1a-3.pdf.

13. Hellenic Cement Industry Association (HCIA). 2002. History of Cement and Concrete.http://www. hcia.gr/3a.html.

14. Henning, O. 1974. Cements: The Hydrated Silicates and Aluminates. In The Infrared Spectra of Minerals, edited by V.C. Farmer, 445-463. London: Mineralogical Society of Great Britain.

15. Herring, B. 2002. The Secrets of Roman Concrete. In Constructor, Virginia: Associated General Contractors of America (AGC).

16. Hughes, J., Groot, C., Bale, V.K., Bicer-Simsir, B., Binda, L., Elsen, J., Hees, R.P.J. 2012. et al., RILEM TC 203-RHM: Repair Mortars for Historic Masonry, The Role of Mortar in Masonry: An Introduction to the Requirements for the Design of Repair Mortars. Materials and Structures, 45(9), 1287-1294, https:// doi.org/10.1617/s11527-012-9847-9.

17. Kourti, I., Rani, D.A., Boccaccini, A.R., Cheeseman, C.R. 2010. Geopolymers from DC Plasma Treated APC Residues, Metakaolin, and GGBFS. Second International Conference on Sustainable Construction Materials and Technologies, 67-76. 
Ancona: Universita Politecnica delle Marche, http:// www.claisse.info/proceedings.htm.

18. Lash, A. 2012. Qasr Tuba. Annual of the Department of Antiquities of Jordan 56, 9-29.

19. Levienspiel, O. 1999. Chemical Reaction Engineering, 3rd Ed., New York: John Wiley.

20. Luxan, M.P., Dorrego, R.F., Laborde. A. 1995. Ancient Gypsum Mortars from St. Engracia (Zaragoza, Spain): Characterization, Identification of Additives and Treatments. Cement and Concrete Research, 25(8), 1755-1765.

21. Murat, M. 1983. Hydration Reaction and Hardening of Calcined Clays and Related Minerals. I. Preliminary Investigation on Metakaolinite. Cement and Concrete Research 13, 259-266.

22. Musil, A. Arabia Petraea I: Moab, Wien: Alfred Holder, 1907.

23. Omeri, I. 2009. Nabatean Mortars: Technology and Application, Damascus: The Syrian General Organization of Books.

24. Palomo A., Blanco-Varela, M.T., Martinez-Ramirez, S., Puertas, F., Fortes, C. 2002. Historic Mortars: Characterization and Durability. New Tendencies for Research. In Advanced Research Centre for Cultural Heritage Interdisciplinary Projects, Prague: Fifth Framework Programme Workshop. https:// pdfs.semanticscholar.org/4c98/1dea63830434c114 ec0688ba3a8a1847845a.pdf?_ga=2.83467286.167 3771409.1595933736-1951099947.1595933736.

25. Rao, G.A. 2003. Investigations on the Performance of Silica Fume: Incorporated Cement Pastes and Mortars. Cement and Concrete Research 33, 1765-1770.

26. Rice, S.B., Freund, H., Huang, W.L., Clouse, J.A., Isaacs, C.M. 1995. Application of Fourier Transform Infrared Spectroscopy to Silica Diagenesis: The opal-A to opal-CT Transformation", Journal of
Sedimentary Research, 65(4a), 639-647.

27. Rossi-Doria, R.P. 1990. Ancient Mortars and Mortars for Restauration. RILEM Bulletin. Report on the RILEM Workshop. Materials and Structures, 23, 235-238.

28. Salameh, E. 1996. Water Quality Degradation in Jordan: Impact on Environment, Economy and Future Generations Resources Base. Amman: Friedrich Ebert Stiftung and Royal Society for the Conservation of Nature.

29. Samtani, M., Dollimore, D. Tong, P., Alexander, K.S.1996. The Kinetic Interpretation of the Decomposition of Calcium Carbonate by Use of Relationships Other than the Arrhenius Equation. Thermochimica Acta 282-283, 13-27.

30. Shaw, I. 2000. Oxford History of Ancient Egypt. Oxford: Oxford University Press.

31. Thomasen, S.E., and Searls, C.L. 1988. Diagnosis of Terra-Cotta Glaze Spalling. In Masonry: Materials, Design, Construction and Maintenance. ASTM STP 992, edited by H. Harris, 227-236. Philadelphia: American Society for Testing \& Materials.

32. Válek, J., Hughes, J.J., Pique, F., Gulotta, D., Hees, R., Papayiani, I. 2019. Recommendation of RILEM TC 243-SGM: Functional Requirements for Surface Repair Mortars for Historic Buildings. Materials and Structures 52, 1-18. https://doi.org/10.1617/ s11527-018-1284-y.

33. Van der Marel, H.W. and Beutelspacher, H. 1976. Atlas of Infrared Spectroscopy of Clay Minerals and their Admixtures. Amsterdam and New York: Elsevier Scientific Publishing Company.

34. Zampieri, V. 1990. Mineralogy and microstructure of reaction products in metakaolinite-lime mixtures. In Proceedings of the 12th International Conference on Cement Microscopy Association, Ducanville, TX, pp. 76-95. E\&FNSpon Routledge, USA. 